\title{
Recontextualising the news
}

\author{
How antisemitic discourses are constructed \\ in extreme far-right alternative media
}

\author{
Birgitte P. Haanshuus ${ }^{\mathrm{I}}$ \& Karoline Andrea Ihlebæk ${ }^{\mathrm{II}}$ \\ I The Norwegian Centre for Holocaust and Minority Studies, Oslo, Norway \\ ${ }^{\text {II }}$ Department of Journalism and Media Studies, Oslo Metropolitan University, Norway
}

\begin{abstract}
This study explores how an extreme far-right alternative media site uses content from professional media to convey uncivil news with an antisemitic message. Analytically, it rests on a critical discourse analysis of 231 news items, originating from established national and international news sources, published on Frihetskamp from 2011-2018. In the study, we explore how news items are recontextualised to portray both overt and covert antisemitic discourses, and we identify four antisemitic representations that are reinforced through the selection and adjustment of news: Jews as powerful, as intolerant and anti-liberal, as exploiters of victimhood, and as inferior. These conspiratorial and exclusionary ideas, also known from historical Nazi propaganda, are thus reproduced by linking them to contemporary societal and political contexts and the current news agenda. We argue that this kind of recontextualised, uncivil news can be difficult to detect in a digital public sphere.
\end{abstract}

Keywords: alternative media, antisemitism, borderline discourse, recontextualisation, uncivility

\section{Introduction}

It is a well-established fact that the Internet has enabled hate groups to engage in a variety of communicative practices, including building online communities and networks; providing information to their supporters; mobilising to activism; engaging in disinformation, propaganda, and hate campaigns; and recruiting new members (Brown, 2009; Caiani \& Parenti, 2016; De Koster \& Houtman, 2008; Ekman, 2019; Haanshuus \& Jupskås, 2017). In this article, we explore practices of online uncivility by investigating how uncivility is conveyed through news produced by uncivil actors - particularly news published on the neo-Nazi website Frihetskamp [Freedom Fight]. The site is owned and run by the Norwegian division of the organisation Nordic Resistance Movement (NRM), which represents an extremist antisemitic worldview and aims to stop and reverse all immigration and the "occupation" of what they describe as the "global Zionistic elite" (Frihetskamp.net, 2016). ${ }^{1}$

Haanshuus, B. P., \& Ihlebæk, K. A. (2021). Recontextualising news: How antisemitic discourses are constructed in extreme far-right alternative media. Nordicom Review, 42(S1), 37-50. https:// doi.org/10.2478/nor-2021-0005 
This article addresses Frihetskamp as an extreme far-right alternative media site. Several studies have explored how far-right alternative media has increasingly managed to impact online agendas through uncivil and exclusionary discourses about immigration and Islam (Benkler et al., 2018; Ekman, 2018; Holt, 2019; Krzyżanowski \& Ledin, 2017; Sandberg \& Ihlebæk, 2019). Furthermore, previous research has shown how such sites mimic the features of professional news media sites and that they often select and amend stories from the established media (Ekman, 2019). In this article, we aim to explore how far-right alternative media function as an arena for antisemitic discourse, and we ask: How are uncivil discourses about Jews constructed through news published on Frihetskamp? More specifically, we focus on the process of recontextualisation, by which we mean how news from professional news organisations is placed in an uncivil discursive context and consequently changes meaning, thus becoming "uncivil news". Also, we look at practices of alteration, where news items are manipulated in small but significant ways to enhance the ideological stance of the site. These amendments, we argue, might not necessarily be noticed by audiences confronted by single news items shared on social media, but the amendments can function as important signifiers for the organisation's followers. A point of departure, then, is that even though NRM is an uncivil actor, their uncivil message may be conveyed in more or less implicit and explicit ways on Frihetskamp. As Krzyżanowski and Ledin (2017: 567) have pointed out, uncivil actors often communicate through "borderline discourses", implying how hateful and exclusionary views that are in stark contrast to liberal-democratic ideals are represented through what apparently looks like civil communicative forms.

Methodologically, this study is inspired by Reisigl and Wodak's $(2001,2016)$ discourse-historical approach - in particular, the socio-diagnostic critique, which aims to uncover the persuasive or "manipulative" character of discursive practices, whether manifest or latent. Based on a strategic selection of 231 news items originating from established news sources and published on Frihetskamp, we analyse how stories are amended to portray both overt and covert antisemitic discourses. On a theoretical level, the study is inspired by perspectives on historical and contemporary antisemitic Nazi discourses (Botsch \& Kopke, 2014; Burrin, 2005; Herf, 2006; Macklin, 2014; Welch, 2002) and particularly how this kind of uncivility can be explored through far-right news production.

Although Frihetskamp as a news site might be described as a marginal phenomenon with limited visibility and reach, we argue that it is of great importance to explore how extremist actors construct and disseminate uncivil content. This is particularly so because antisemitism appears to be on the rise in Europe and the US. Recent reports have emphasised how online media plays an important role in this development (Anti-Defamation League, 2018; Community Security Trust, 2018, 2020; European Union Agency for Fundamental Rights, 2018), but so far, the topic has been given limited scholarly attention. We argue that it is of particular concern that the website in question to a large degree mimics the visual layout and content of professional online newspapers, which potentially can mislead audiences who are not necessarily supportive of NRM's cause, but who are unfamiliar with the symbols and language of neo-Nazis. Furthermore, by utilising news produced by legitimate news media that adheres to professional ethical standards, NRM constructs their uncivil message in a way that can be difficult to detect. In a Norwegian context, there have been several examples of how news content 
from Frihetskamp has been shared on social media by people presumably unaware of the site's extremist stance (Klungtveit, 2020). By deconstructing news published on Frihetskamp, this study contributes with knowledge concerning how antisemitism is expressed in high-choice digital media environments, where the threshold for producing and distributing content is low and where it is increasingly difficult to distinguish between civil and uncivil information providers.

\section{Uncivil news in far-right alternative media}

The digital media environment is characterised by a dramatic proliferation of actors that produce and distribute content (Chadwick, 2013; Marwick \& Lewis, 2017). While online platforms undoubtedly have enabled valuable democratic participation from new groups in society (Papacharissi, 2004), the rise of online uncivility and hate speech has been identified as a democratic problem (European Commission, 2016; United Nations, 2019). Previous research has indicated that far-right actors have developed active media strategies to gain media attention (Baugut \& Neumann, 2019) and that they utilise online communication structures to produce and distribute uncivil content to gain visibility and impact in the online environment (Caiani \& Parenti, 2016; Marwick \& Lewis, 2017).

In this article, we focus on uncivility in the context of far-right alternative media, meaning websites consisting of hyper-partisan and ideologically driven news (Figenschou \& Ihlebæk, 2019; Heft et al., 2019; Holt, 2019; Ihlebæk \& Nygaard, 2021). The literature on alternative media has traditionally been rooted in social movement theory, which emphasises that alternative media should strengthen democratic goals through participation and empowerment of marginalised groups (Atton, 2002; Haas, 2004). In recent years, however, there has been an increase in what can be described as right-wing to far-right alternative news media, characterised partly of uncivil and undemocratic discourses, specifically when it comes to topics such as immigration, integration, and Islam (Atkinson \& Berg, 2012; Figenschou \& Ihlebæk, 2019; Holt, 2019; Nygaard, 2019, 2020). Whether far-right alternative media based on exclusionary views should be termed alternative has consequently been questioned (Atton, 2006; Padovani, 2016). In this article, we refer to Holt and colleagues (2019: 863), who have proposed a non-normative definition of alternative media: "Alternative news media represent a proclaimed and/or (self) perceived corrective, opposing the overall tendency of public discourse emanating from what is perceived as the dominant mainstream media in a given system". Following this definition, a key trait of alternative media is the relational aspect and how the term alternative is used to identify an oppositional position. In the case of Frihetskamp, their counter-position to the "lying media" is stated on their website through the slogan "In times of universal deceit and lies, telling the truth is a revolutionary act". It is also worth noting that "the lying press" (or Lügenpresse) is a historical term that was used by the Nazi regime to discredit the news media and to undermine public trust (Koliska \& Assmann, 2019).

In this article we argue that far-right alternative media can be viewed as a form of "bottom-up incivility" (Krzyżanowski \& Ledin, 2017: 569), referring to how online platforms are used by amateurs and activists to express controversial, hateful, and extremist views to a wider audience. Following Krzyżanowski and Ledin's (2017) line of thought, 
we propose that far-right alternative media can be viewed as uncivil arenas because of the undemocratic or racist ideologies that constitute the basis for their practices. In contrast, professional online news media structured around journalistic professionalism and institutionalised ethics can be characterised as civil arenas of communication. The boundaries between what is deemed professional or non-professional - and civil or uncivil - is of course not clear-cut, or easily detectable in many cases (Carlson, 2015). Crude tabloid journalism, for instance, might break with the normative ideals of professional journalism and contribute to uncivil discourses about certain groups in society. Also, news published on what can be described as uncivil arenas may be conveyed through expressions that might, at first glance, seem civil. For instance, hateful discourses might be disguised by far-right actors by mimicking "real news" (Farkas \& Neumayer, 2020). Studies have shown how far-right actors, rather than making up stories, often depend heavily on content from established news sources (Ekman, 2019; Haller \& Holt, 2019; Krzyżanowski $\&$ Ledin, 2017). Consequently, what can be described as a process of recontextualisation occurs, which is when an element is taken out of one context and used in another, subsequently giving it a new meaning (Ekman, 2019; Krzyżanowski, 2016; Reisigl \& Wodak, 2016). In the context of this article, recontextualisation refers to when a news story originally published on what can be described as a civil arena (established media) is republished on an uncivil arena (far-right alternative media) and is thus ideologically re-positioned. Furthermore, the original news item can be adjusted through extensive or small symbolic editorial amendments - for instance, through changing the headline, a picture, or parts of the text (Ekman, 2019). As a consequence, seemingly civil news items are manipulated into uncivil news, by which we mean news published on uncivil arenas with the purpose of implicitly or explicitly conveying hateful discourses about particular groups in society.

To be able to understand how uncivil discourses about Jews are constructed through news on Frihetskamp, it is necessary to place our study within a historical context on how antisemitic discourses have been expressed both overtly and covertly.

\section{Antisemitic representations in Nazi propaganda: A brief historical overview}

Hostility and prejudice against Jews have deep historical roots, from ancient times to present day. The vast literature has demonstrated, on the one hand, how the phenomenon has changed and adapted through history and, on the other hand, how many myths and stereotypes about Jews have been reproduced (Chazan, 1997; Laqueur, 2006). For the purpose of this study, it is necessary to highlight some antisemitic representations that are well known from Nazi propaganda.

At the core of Nazi ideology is the conspiratorial idea of a hidden, powerful Jewish network aiming for world domination. In the years before the persecution and systematic killing of six million Jews, they were portrayed as influential scapegoats responsible for the downfall of Germany. Jews were seen as an alien element and were held accountable for all negative trends in society, including cultural, economic, and political grievances (Herf, 2006; Welch, 2002). Furthermore, Jews were regularly presented as evil, moneygrabbing capitalists or communists, and the propaganda on racial issues often framed Jews as criminals (Welch, 2002). Nazi propaganda of the 1940s presented Germany's 
war against the Allies and the fight against the Jews as a revenge-and-defence tactic. This "radical antisemitism" was based on the belief that the Jews were a cohesive, politically active, and powerful entity, and if not identified and destroyed, "international Jewry" would eradicate the German people (Herf, 2006: 7). In this narrative, Germans were portrayed as victims and Jews as the ultimate enemy. Moreover, Jews have also frequently been depicted as parasites, rats, carriers of infection, germs, and plagues, or as poisonous demons - all dehumanising metaphors that point to the need for extermination (Burrin, 2005; Welch, 2002).

Following World War II, antisemitism is no longer accepted in the public sphere but continues to be an essential part of far-right ideology - in particular within the antidemocratic extreme right. In this context, Botsch and Kopke (2014) have argued that antisemitism has undergone a process of transformation, in which euphemistic language plays an important role. They distinguish between "primary antisemitism" or the continuation of the traditional racist antisemitism of the Nazis - and "secondary antisemitism" - when antisemitic ideas are concealed by reversing the roles of victims and perpetrators. In this regard, a common antisemitic sentiment is to deny or downplay the severity of the Holocaust and accuse the Jews of exploiting their victim status. Other strategies of concealment include imitating the language of liberal democracy to legitimise exclusionary sentiments without making use of traditional racist argumentation, or replacing the word Jew with labels such as "Zionist", "globalist", or "international money power", so that antisemitic ideas are reproduced without explicitly mentioning Jews (Botsch \& Kopke, 2014; Macklin, 2014). Simonsen (2020: 655) has suggested that far-right actors who seek mass support tend to moderate themselves and use coded language more often than militant "racist-revolutionaries", such as NRM.

\section{Case, data, and method}

The website under scrutiny, Frihetskamp, is the main digital media platform of the Norwegian division of NRM, which is the largest and most prominent neo-Nazi organisation in the Nordic countries. Originally established in Sweden in 1997 under the name Swedish Resistance Movement, the Swedish parent organisation merged with its smaller offspring organisations in Finland, Norway, and Denmark in 2016 (Ravndal, 2018). While NRM continues to be primarily a Swedish organisation, it has in the past few years become more visible and increasingly gained attention from media and authorities in Norway as well (Bjørgo \& Gjelsvik, 2018). All of NRM's national divisions have websites in their own languages, with the (current) Norwegian division and its website first appearing in 2011. The organisation has an active media strategy of filming their own activities, provoking confrontations, and offering daily coverage of domestic and foreign news (see also Askanius, 2019). In addition, they frequently publish podcasts, essays on historical events and topics, reports about their offline activities, commentary and opinion pieces written by NRM members, and letters to the editor written by guest writers.

In the analysis, our aim has been to expose how antisemitism is conveyed through recontextualised news - meaning news stories that originate from the established mediaon Frihetskamp. Inspired by Reisigl and Wodak's (2001, 2016) discourse-historical approach - more specifically, the socio-diagnostic critique, which aims to uncover the 
manifest or latent discriminatory and "manipulative" character of discursive practices - we used an exploratory, inductive three-step procedure.

First, as proposed by Reisigl and Wodak (2016), we identified a specific set of content on Frihetskamp: news that explicitly concerned Jews. We then selected a strategic sample of news items published on Frihetskamp by using the search word jød* [Jew*]. Using the search function on the website, we consequently collected all articles containing the search word published on Frihetskamp between 2011 and $2018(N=675)$. As we went through the material, it became clear that Frihetskamp linked to material from a variety of sources, including other alternative media sites, content from social media platforms, and other online sources. Both researchers then went through the articles and identified stories that linked to international and national established news media $(N=231)$, by which we mean professional news sites with an ascribed editor and that adheres to an established ethical code of conduct. ${ }^{2}$

Second, to uncover discursive strategies - more specifically, to examine in more detail how news stories recontextualised from established media convey antisemitic representations - we used the analytical questions proposed by Reisigl and Wodak (2001) to conduct a close reading of the texts:

- How are Jews and "the Jewish" referred to?

- What characteristics, traits, and features are attributed to them?

- What arguments are used to justify and legitimise exclusionary views on Jews?

- From what perspective or point of view are these labels, attributions, and arguments expressed?

- Are the exclusionary and discriminatory utterances articulated overtly or covertly?

Our aim was not to conduct a comprehensive linguistic analysis and answer these questions separately but rather to use them as a guideline to illuminate how news stories from civil actors are placed in new discursive contexts and consequently become uncivil news with an antisemitic message.

Third, we examined how specific linguistic means are used to alter news and thus function to convey antisemitic messages both explicitly and implicitly. The examples highlighted in the analysis below illustrate specific strategies and represent a subset of news stories that are altered in similar ways and thus convey a similar message.

\section{Analysis: The antisemitic representations in uncivil news}

Our findings show that there are four distinct forms of antisemitic representations that stand out when news items from established sources are selected and recontextualised by NRM on Frihetskamp: 1) the Jews as powerful, 2) the Jews as intolerant and anti-liberal, 3 ) the Jews as exploiters of victimhood, and 4) the Jews as inferior. In the following text, we outline these representations in more detail and point out how they are constructed around specific traits, features, and arguments about Jews that are well known from historical Nazi discourse. We also explore how specific forms of alterations that are used when recontextualising news stories function to convey antisemitic messages in both overt and covert ways. 


\section{The powerful Jews}

The first representation we found is that Jews are portrayed as powerful actors aiming for world domination. By recontextualising news stories about politics and societal affairs from the established press, in which (alleged) Jewish individuals or organisations are involved, NRM revives old antisemitic ideas known from traditional Nazi propaganda. On Frihetskamp, Jews are characterised as influential scapegoats who work behind the scenes and are responsible for what is deemed destructive trends in society, including increased immigration, dissolution of traditional gender roles, biased media, and restrictions on freedom of expression.

To illustrate this point, recontextualised news stories about investor and philanthropist George Soros echo the historical and conflicting antisemitic myth of Jews as powerful, corrupt capitalists who are also linked to left-wing ideology. The focus of these news stories is on how Soros and his organisation, Open Society Foundations, have financed and organised political initiatives, including immigration, anti-racist campaigns and riots, and demonstrations for gay rights and women's rights. While the mainstream media sources (e.g., Melén, 2018; Riddell, 2015) simply refer to Soros with labels such as "Hungarian-American businessman" or "liberal billionaire", NRM systematically refers to him as a "Jewish multibillionaire" on Frihetskamp. By emphasising his alleged Jewish identity and connecting it to features such as being rich, influential, and leftist, NRM has made Soros into a symbol of Jews as the ultimate political enemy. Similarly, Facebook founder Mark Zuckerberg and non-governmental organisations such as Anti-Defamation League and Southern Poverty Law Center, who monitor and prevent right-wing extremism, are also identified as Jewish and portrayed as particularly powerful opponents that actively promote liberal immigration policies and strict hate speech legislation. The overall argument is that these influential Jewish actors work to undermine the ideological cause of NRM and others who share their worldview. While it can be argued that emphasising the "Jewishness" of the actors in question makes the antisemitic message quite explicit, it may also function as a way of promoting a comprehensive antisemitic conspiracy theory about Jewish power by simply referring to individuals, organisations, or institutions as "Jewish".

Also part of this discourse in which Jews are attributed power, we found that media in general, or specific media enterprises such as Bonnier and news outlets such as The New York Times, are referred to as Jewish or Jewish-owned. Identifying the media as Jewish thus functions as a way of labelling the established press as a lying and powerful enemy that is suppressing "nationalists" and free speech, as well as promoting a left-wing, "cultural Marxist" agenda. Furthermore, the emphasis on media as Jewish or Jewish-owned reproduces the antisemitic myth of Jews as particularly influential in media and, consequently, also the public debate on politics. This points to the paradoxical relationship far-right alternative news media has to the established press, which is to them both a useful source and a useful enemy.

\section{The intolerant and anti-liberal Jews}

The second antisemitic representation that is reinforced through the recontextualisation of news is Jews as intolerant and against liberal democratic values. By recontextualising news from established media about hate speech and other political issues, including 
news coverage about Israel, NRM presents themselves as tolerant and Jews as illiberal opponents of the democratic system and democratic values such as freedom of speech and equality. This is also connected to ideas about Jewish power, but as emphasised in previous research on antisemitic and extremist rhetoric (Macklin, 2014), the use of a seemingly democratic language that focuses on the illiberal or undemocratic characteristics of Jews functions as a way of legitimising exclusionary manifestations without making use of traditional racist argumentation.

To reinforce this discourse, mainstream news coverage on antisemitic hate speech and proposals to ban Holocaust denial are recontextualised. More specifically, on Frihetskamp, news stories on these topics are used to "prove" that freedom of expression is limited and that Jews are at the forefront of pushing such restrictions. This can be illustrated by a news story on how the president of the World Jewish Congress has criticised a Hungarian business magazine for reproducing antisemitic stereotypes about Jewish financial power and asked the Hungarian prime minister, Viktor Orbán, to condemn it. While the original story from Israeli news outlet $i 24$ News focused on Orbán's dismissal of the request, NRM used the story and a quote by Orbán to implicitly argue that Jews - in this case represented by the World Jewish Congress - are "restricting freedom of speech and freedom of the press". Other similar news stories on Frihetskamp focus on how Jewish leaders and politicians are working to introduce legislation that "serves Jewish interests", such as criminalising hate speech and Holocaust denial. The overall argument is that it should be legitimate and legal to do what NRM refer to as "criticising" Jews, Jewish power, and Jewish corruption. However, since Jews control the media and are powerful in politics, they also control the public debate and legislation on hate speech - and they do it in a hypocritical and excluding way that threatens freedom of speech. In a similar manner, NRM also recontextualises news stories to claim that Jews are at the forefront of attempting to limit the American constitutional right to bear arms, and Jews are framed as strong opponents of elected politicians such as President Donald Trump and the right-wing government in Austria, thus insinuating that Jews do not respect the democratic system, at least not as long as it is governed by right-wing politicians. These ideas are also implicitly or explicitly connected to the theory of a Jewish conspiracy aiming for world domination and deliberately seeking to break down society.

Also part of this seemingly democratic language is a common claim or insinuation that Jews discriminate against others. In this context, mainstream news coverage on Israeli politics is recontextualised to suggest that Jews have a racist and exclusionary worldview, in this case represented by "the Jewish State of Israel". To illustrate, while a news story from Norwegian newspaper Dagbladet cites the Israeli prime minister, Benjamin Netanyahu, saying, "Israel is prepared for mass immigration [of European Jews]" after the recent terrorist attacks aimed at Jewish targets in Paris and Copenhagen (Andersen, 2015), the news story on Frihetskamp emphasises that "Israel is ready for mass immigration, but only of Jews". The quote by Netanyahu is thus slightly adjusted to highlight NRM's view of Jews as discriminatory. Other recontextualised news articles refer to the discrimination and segregation of Palestinians and the so-called "race laws" implemented by Israel that differentiates between Jews and non-Jews, to frame Jews (in general) as racists and hypocrites. 


\section{The Jews as exploiters of victimhood}

The third antisemitic representation is Jews as exploiters of victimhood. By recontextualising news stories from the established press on antisemitism, racism, and hate crime aimed at Jewish targets, NRM - often in an implicit way - trivialises or denies that Jews have been victims of violence and hate. While the mainstream media sources that they make use of describe the details of and reactions to terrorist attacks and hate crime targeting Jewish individuals or institutions in a neutral and civil manner, the recontextualised news on Frihetskamp characterises Jews as easily violated and focus on how they deliberately exaggerate and exploit their (historical) status as victims, which is a form of so-called secondary antisemitism (Botsch \& Kopke, 2014).

This narrative was particularly visible in early 2015, after the terrorist attacks on Charlie Hebdo and a kosher supermarket in Paris and a synagogue in Copenhagen. To illustrate, in an article from Norwegian newspaper Aftenposten, the leader of the Jewish Community of Oslo said that "Norway is one of the better countries for Jews to live in, but we are a bit more vulnerable than most Norwegians. Extremists depend on creating enemy images, and Jews are one of the most central [translated]" (Sætran, 2015). When this news story was recontextualised on Frihetskamp, the quote was cut and only included "We [the Jews] are a bit more vulnerable than most Norwegians". Further, the news story on Frihetskamp highlighted that Jews "receive special protection". Other similar stories focus on how Jews demand special treatment. Although not necessarily overtly articulated, a general argument throughout these news stories is that Jews use their alleged experience and position as victims to strengthen their influence and gain benefits.

Similarly, a news story originally from Norwegian newspaper Vårt Land [Our Country] on how "well-known Norwegian Jews are worried" about the increasing threat against Jewish targets was recontextualised to trivialise the Jewish experience of insecurity (Lindvåg, 2015). When the news story was covered on Frihetskamp, quotation marks were used to change the meaning of the word "worried", thus insinuating that the Jews mentioned were worried for no reason. The explanation for this argument is found in other news articles suggesting that Jewish individuals are responsible for staging antisemitic hate crimes. In these stories, NRM consistently refers to the hate crimes using quotations marks.

When recontextualising news on these topics, NRM systematically refers to antisemitism and hate crime with quotation marks or as "so-called" or "alleged" antisemitic events - small amendments and linguistic means that are used to express irony or doubt. In its most extreme form, this type of ironic and trivialising language is also used to covertly communicate Holocaust denial. When recontextualising news about the Holocaust, NRM refers to it as "Holocaust" - with quotation marks. People claiming to be survivors of the Holocaust are referred to as "survivors" (also with quotation marks) or "so-called survivors". Other examples of this type of language include phrases such as "Six million Jews were supposedly killed during World War II" and a story about how a former guard in Auschwitz, who is now convicted of being an accomplice in genocide, "admits that he worked as a chef but has never seen gas chambers during his time there". While the mainstream media sources these news stories are based on never question the historical facts of the Holocaust, news on Frihetskamp insinuates that the genocide is exaggerated or that it never happened. The overall argument is that the Jews themselves 
are responsible for the threats against them and that they are lying about their vulnerability and exploiting their alleged victimhood.

\section{The inferior Jews}

A fourth antisemitic representation is when Jews are presented as inferior. By this we mean news where the most explicit and crude antisemitic manifestations occur, such as when Jews are referred to with dehumanising metaphors or racist or prejudiced slurs. A general finding in our study is that relatively few examples of such explicit or derogatory antisemitic content appear in the news published on Frihetskamp. A key tendency is that when such explicit uncivil expressions occur, NRM does not present it as their own view. Rather they report what others have said that is explicitly antisemitic, thus disguising the uncivil message as presented by others.

Examples of such dehumanising metaphors and racist slurs on Frihetskamp include news reports about a Dutch professor who has referred to Jews as "evil parasites", an American left-wing activist who was arrested for tagging "Die Jew Rats" on a synagogue, and a Norwegian hip-hop artist who was reported for saying "fuck Jews" from stage. The news coverage also included examples of dehumanising language set in a historical context. A story on a recently published book about famous Norwegian author Knut Hamsun, known to have expressed sympathies for Nazi Germany, highlighted a quote by Hamsun's wife, Marie, which echoes the dehumanising antisemitic propaganda of the 1940s calling for extermination: "Jews are the devils behind every war; they are the rotten flesh of a human's body". Other examples include news reports about prominent individuals who - intentionally or unintentionally - have expressed explicit racist or prejudiced ideas about Jews and thus are being accused of antisemitism. This can be illustrated by a news story on how famous footballer Mario Balotelli posted a discriminatory picture of the video game character Mario on his Instagram account. The picture claims that "He [Mario] is an Italian plumber" who "jumps like a black man, and grabs coins like a Jew". Balotelli's social media post has consequently been criticised for being racist and reproducing the antisemitic stereotype of Jews as greedy. Balotelli has later apologised and argued that it was supposed to be an anti-racist joke. On Frihetskamp, however, the underlying argument is that he should not have apologised and that Jews lack humour and are easily violated. By simply referring to quotes by others, NRM can convey explicit antisemitic language - including dehumanising, racist, and prejudiced sentiments - without it being obvious that they are an inherently antisemitic and uncivil news publisher.

\section{Conclusion}

In this study, we have explored how antisemitic discourses are constructed on Frihetskamp, a far-right alternative media site that can be characterised as an uncivil arena because of its antidemocratic and exclusionary stance. Our point of departure was that far-right alternative media, which mimics the outline and features of established news media, can be viewed as a form of "bottom-up incivility" (Krzyżanowski \& Ledin, 2017: 569), in which amateurs and activists express hateful and extreme views through the production of news. Previous research has indicated that the organisation under scrutiny has 
an active media strategy (Askanius, 2019). Inspired by Reisigl and Wodak's (2001, 2016) discourse-historical approach, our aim has been to uncover the manifest or latent discriminatory and manipulative character of such discursive practices by illuminating how NRM recontextualises and adjusts content from legitimate news providers, thus transforming civil news into uncivil news. We have argued that by recontextualising and adjusting news stories from the established press, NRM presents news coverage that constitutes an exclusionary antisemitic worldview in both overt and covert ways.

This study has identified four antisemitic representations that are reinforced through the selection and recontextualisation of news on Frihetskamp: the Jews as powerful, as intolerant and anti-liberal, as exploiters of victimhood, and as inferior. These exclusionary and conspiratorial ideas, also known from historical Nazi propaganda, are thus reproduced on Frihetskamp by connecting them to contemporary societal and political contexts and the current news agenda. The overall argument on Frihetskamp is that Jews are the ultimate enemy and the common denominator behind all development deemed destructive in society, including immigration, multiculturalism, financial power, and restrictions on freedom of speech (see also Simonsen, 2020). In other words, and as pointed out by Herf (2006: 183) in his study on Nazi propaganda of the 1940s, "the Jews are guilty of everything". However, this overarching message is presented in bits and pieces throughout the news coverage - often by implicit means. Consequently, without readers having knowledge about historical antisemitic manifestations, the uncivility of the news about Jews can be difficult to discover. Furthermore, by imitating the format of professional news providers and using stories from such sources, NRM reproduces their antisemitic message through the words of others. Our study also found that when explicit derogatory antisemitic expressions - such as dehumanising metaphors and racist slurs - are conveyed, they often occur in news stories where others are reported as expressing them. In this way, and as similarly emphasised by Macklin (2014), NRM seeks to legitimise their antisemitic worldview without making use of explicit racist argumentation. Avoiding or distancing themselves from explicit hostile language reduces the risk of legal sanctions - for instance, through hate speech legislation - and it makes their antisemitic message more covert and difficult to identify.

The fact that the news coverage on Frihetskamp is based on actual news from the established media and with traceable sources may create a sense of legitimacy that blurs the boundaries between the civil and uncivil. The alternative news site under scrutiny can thus be considered an example of a borderline discourse of uncivility (Krzyżanowski $\&$ Ledin, 2017), where hateful and exclusionary views are represented through what might seem like a civil communicative form. This is of great concern, because as the digital sphere has become more complicated and messy, and is a place where a great variety of actors compete for our attention, uncivil actors might reach new audiences and manage to infiltrate the social media sphere with uncivil content. This problem has been recognised by global media platforms such as Facebook and YouTube, and recent measures have been taken to exclude uncivil actors from spreading their content through their channels. Nevertheless, it is likely that uncivility will continue to spread online, and consequently it is important to pay attention to where and how uncivil actors disseminate their harmful messages.

There are some limitations to this study that must be addressed. We have only investigated news items which explicitly mention the word "Jew". Future research should look 
at how antisemitic sentiments may also be expressed in even more implicit ways - for instance by using code words such as Zionist, globalist, or other dog-whistle strategies - as well as by examining how antisemitic discourses are constructed in other forms of content published on the site, such as historical essays, podcasts, and radio programmes. Finally, we currently know little about how Frihetskamp is used by NRM's members, to what degree they manage to gain visibility and impact amongst other user groups, or what kind of role they play within wider Nordic or international far-right networks. This kind of knowledge is necessary to identify how antisemitism takes places and potentially reaches new publics in a fast-changing digital media environment.

\section{Funding}

This study has been funded by the Norwegian Research Council (project number 272000).

\section{Notes}

1. All quotations from Frihetskamp - and the originating articles - have been translated by the authors.

2. An overview of the news items can be made available by the authors as an Excel file with URLs upon request.

\section{References}

Andersen, Ø. (2015, February 15). - Israel forberedt på masseinnvandring [- Israel prepared for mass immigration]. Dagbladet. https://www.dagbladet.no/nyheter/israel-forberedt-pa-masseinnvandring/60834334

Anti-Defamation League. (2018). Computational propaganda, Jewish-Americans and the 2018 midterms: The amplification of anti-Semitic harassment online. New York: Anti-Defamation League. https://www. adl.org/media/12028/download

Askanius, T. (2019). Studying the Nordic Resistance Movement: Three urgent questions for researchers of contemporary neo-Nazis and their media practices. Media Culture \& Society, 41(6), 878-888. https:// doi.org/10.1177/0163443719831181

Atkinson, J., \& Berg, S. (2012). Narrowmobilization and Tea Party activism: A study of right-leaning alternative media. Communication Studies, 63(5), 519-535. https://doi.org/10.1080/10510974.2011.649442

Atton, C. (2002). Alternative media. London: Sage. http://dx.doi.org/10.4135/9781446220153

Atton, C. (2006). Far-right media and the internet: Culture, discourse and power. New Media \& Society, 8(4), 573-587. https://doi.org/10.1177/1461444806065653

Baugut, P., \& Neumann, K. (2019). How right-wing extremists use and perceive news media. Journalism \& Mass Communication Quarterly, 96(3), 696-720. https://doi.org/10.1177/1077699018803080

Benkler, Y., Faris, R., \& Roberts, H. (2018). Network propaganda: Manipulation, disinformation, and radicalization in American politics. Oxford: Oxford University Press. https://doi.org/10.1093/ oso/9780190923624.001.0001

Bjørgo, T., \& Gjelsvik, I. M. (2018). Utvikling og utbredelse av høyreekstremisme i Norge [Development and prevalence of right-wing extremism in Norway]. In T. Bjørgo (Ed.), Høyreekstremisme i Norge: Utviklingstrekk, konspirasjonsteorier og forebyggingsstrategier [Right-wing extremism in Norway: Developments, conspiracy theories, and strategies for prevention] (pp. 27-144). Oslo: Norwegian Police University College.

Botsch, G., \& Kopke, C. (2014). A case study of anti-Semitism in the language and politics of the contemporary far right in Germany. In M. Feldman, \& P. Jackson (Eds.), Doublespeak: The rhetoric of the far right since 1945 (pp. 207-221). Stuttgart: ibidem Press.

Brown, C. (2009). WWW.HATE.COM: White supremacist discourse on the Internet and the construction of whiteness ideology. Howard Journal of Communications, 20(2), 189-208. https://doi. org/10.1080/10646170902869544

Burrin, P. (2005). Nazi antisemitism: Animalization and demonization. In R. S. Wistrich (Ed.), Demonizing the other: Antisemitism, racism, and xenophobia (pp. 221-235). London: Routledge. https://doi. org/10.4324/9780203727249

Caiani, M., \& Parenti, L. (2016). European and American extreme right groups and the Internet. London: Routledge. https://doi.org/10.4324/9781315580845 
Carlson, M. (2015). Introduction: The many boundaries of journalism. In M. Carlson, \& S. C. Lewis (Eds.), Boundaries of journalism: Professionalism, practices and participation (pp. 1-19). London: Routledge. https://doi.org/10.4324/9781315727684

Chadwick, A. (2013). The hybrid media system: Politics and power. Oxford: Oxford University Press. https:// doi.org/10.1093/acprof:oso/9780199759477.001.0001

Chazan, R. (1997). Medieval stereotypes and modern antisemitism. Berkeley, California: University of California Press.

Community Security Trust. (2018). Antisemitic content on Twitter. London: Community Security Trust. https:// cst.org.uk/public/data/file/4/2/Antisemitic\%20Content\%20on\%20Twitter.pdf

Community Security Trust. (2020). Antisemitic incidents 2019. London: Community Security Trust. https:// cst.org.uk/data/file/9/0/IncidentsReport2019.1600688575.pdf

De Koster, W., \& Houtman, D. (2008). 'Stormfront is like a second home to me': On virtual community formation by right-wing extremists. Information, Communication \& Society, 11(8), 1155-1176. https:// doi.org/10.1080/13691180802266665

Ekman, M. (2018). Anti-refugee mobilization in social media: The case of Soldiers of Odin. Social Media + Society. (January-March), 1-11. https://doi.org/10.1177/2056305118764431

Ekman, M. (2019). Anti-immigrant sentiments and mobilization on the Internet. In K. Smets, K. Leurs, M. Georgiou, S. Witterborn, \& R. Gajjala (Eds.), The Sage handbook of media and migration (pp. 551-562). London: Sage.

European Commission. (2016). The EU Code of conduct on countering illegal hate speech online. https:// ec.europa.eu/info/policies/justice-and-fundamental-rights/combatting-discrimination/racism-and-xenophobia/eu-code-conduct-countering-illegal-hate-speech-online_en

European Union Agency for Fundamental Rights. (2018). Experiences and perceptions of antisemitism: Second survey on discrimination and hate crime against Jews in the EU. Vienna: European Union Agency for Fundamental Rights. https://fra.europa.eu/sites/default/files/fra_uploads/fra-2018-experiences-and-perceptions-of-antisemitism-survey_en.pdf

Farkas, J., \& Neumayer, C. (2020). Mimicking news: How the credibility of an established tabloid is used when disseminating racism. Nordicom Review, 41(1), 1-17. https://doi.org/10.2478/nor-2020-0001

Figenschou, T. U., \& Ihlebæk, K. A. (2019). Challenging journalistic authority: Media criticism in far-right alternative media. Journalism Studies, 20(9), 1221-1237. https://doi.org/10.1080/1461670X.2018.1500868

Frihetskamp.net. (2016, March 5). Vår politikk [Our politics]. https://www.frihetskamp.net/var-politikk/

Haanshuus, B. P., \& Jupskås, A. R. (2017). Høyreklikk! En analyse av ytre høyre på sosiale medier i Norge [The right click! An analysis of the far right in Norway on social media]. Tidsskrift for samfunnsforskning, 58(2), 145-165.

Haas, T. (2004). Research note: Alternative media, public journalism and the pursuit of democratization. Journalism Studies, 5(1), 115-121. https://doi.org/10.1080/1461670032000174783

Haller, A., \& Holt, K. (2019). Paradoxical populism: How PEGIDA relates to mainstream and alternative media. Information, Communication \& Society, 22(12), 1665-1680. https://doi.org/10.1080/136911 8X.2018.1449882

Heft, A., Mayerhöffer, E., Reinhardt, S., \& Knüpfer, C. (2019). Beyond Breitbart: Comparing right-wing digital news infrastructures in six Western democracies. Policy \& Internet, 12(1), 20-45. https://doi. org/10.1002/poi3.219

Herf, J. (2006). The Jewish enemy: Nazi propaganda during World War II and the Holocaust. Cambridge: Harvard Belknap.

Holt, K. (2019). Right-wing alternative media. London: Routledge. https://doi.org/10.4324/9780429454691

Holt, K., Figenschou, T. U., \& Frischlich, L. (2019). Key dimensions of alternative news media. Digital Journalism, 7(7), 860-869. https://doi.org/10.1080/21670811.2019.1625715

Ihlebæk, K. A., \& Nygaard, S. (2021). Right-wing alternative media in the Scandinavian political communication landscape. In E. Skogerbø, Ø. Ihlen, N. N. Kristensen, \& L. Nord (Eds.), Power, communication, and politics in the Nordic countries (pp. 263-282). Gothenburg: Nordicom, University of Gothenburg. https://doi.org/10.48335/9789188855299-13

Klungtveit, H. S. (2020). Nynazister blant oss: På innsiden av den nye høyreekstremismen. [Neo-Nazis among us: On the inside of the new right-wing extremism]. Oslo: Kagge Forlag.

Koliska, M., \& Assmann, K. (2019, December 11). Lügenpresse: The lying press and German journalists' responses to a stigma. Journalism. Online first. https://doi.org/10.1177/1464884919894088

Krzyżanowski, M. (2016). Recontextualisation of neoliberalism and the increasingly conceptual nature of discourse: Challenges for critical discourse studies. Discourse \& Society, 27(3), 308-321. https://doi. org/10.1177/0957926516630901

Krzyżanowski, M., \& Ledin, P. (2017). Uncivility on the web: Populism in/and the borderline discourses of exclusion. Journal of Language and Politics, 16(4), 566-581. https://doi.org/10.1075/jlp.17028.krz 
Laqueur, W. (2006). The changing face of antisemitism: From ancient times to the present day. Oxford: Oxford University Press.

Lindvåg, A. W. H. (2015, January 17). Norske jøder: Utviklingen går i feil retning. [Norwegian Jews: The development is going in the wrong direction]. Vårt Land. https://www.vl.no/samfunn/norske-joderutviklingen-gar-i-feil-retning-1.311446

Macklin, G. (2014). 'Teaching the truth to the hardcore': The public and private presentation of BNP ideology. In M. Feldman, \& P. Jackson (Eds.), Doublespeak: The rhetoric of the far right since 1945 (pp. 123-146). Stuttgart: ibidem Press.

Marwick, A., \& Lewis, R. (2017). Media manipulation and disinformation online. New York: Data \& Society Research Institute. https://datasociety.net/library/media-manipulation-and-disinfo-online/

Melén, J. (2018, May 15). George Soros lämnar Ungern [George Soros leaves Hungary]. Sveriges Radio. https://sverigesradio.se/sida/artikel.aspx?programid=83\&artikel=6953062

Nygaard, S. (2019). The appearance of objectivity: How immigration-critical alternative media report the news. Journalism Practice, 13(10), 1147-1163. https://doi.org/10.1080/17512786.2019.1577697

Nygaard, S. (2020). Boundary work: Intermedia agenda-setting between right-wing alternative media and professional journalism. Journalism Studies, 21(6), 766-782. https://doi.org/10.1080/146167 0X.2020.1722731

Padovani, C. (2016). The media of the ultra-right: Discourse and audience activism online. Journal of Language and Politics, 15(4), 399-421. https://doi.org/10.1075/jlp.15.4.02pad

Papacharissi, Z. (2004). Democracy online: Civility, politeness, and the democratic potential of online political discussion groups. New Media \& Society, 6(2), 259-283. https://doi.org/10.1177/1461444804041444

Ravndal, J. (2018). Ring-wing terrorism and militancy in the Nordic countries: A comparative case study. Terrorism and Political Violence, 30(5), 772-792. https://doi.org/10.1080/09546553.2018.1445888

Reisigl, M., \& Wodak, R. (2001). Discourse and discrimination: Rhetorics of racism and antisemitism. London: Routledge. https://doi.org/10.4324/9780203993712

Reisigl, M., \& Wodak, R. (2016). The discourse-historical approach (DHA). In R. Wodak, \& M. Meyer (Eds), Methods of critical discourse studies (pp. 23-61). London: Sage.

Riddell, K. (2015, January 14). George Soros funds Ferguson protests, hopes to spur civil action. The Washington Times. https://www.washingtontimes.com/news/2015/jan/14/george-soros-funds-ferguson-protestshopes-to-spur/\#ixzz3Ovfpyi5h

Sandberg, L. A. C., \& Ihlebæk, K. A (2019). Start sharing the news: Exploring the link between right-wing alternative media and social media during the Swedish 2018 election. Statsvetenskapelig Tidsskrift, 121(3), 421-439. https://journals.lub.lu.se/st/article/download/19816/17898

Simonsen, K. B. (2020). Antisemitism on the Norwegian far-right, 1967-2018. Scandinavian Journal of History, 45(5), 640-662. https://doi.org/10.1080/03468755.2020.1726809

Sætran, F. (2015, January 12). Sier at politiet har styrket vaktholdet ved synagogen i Oslo [Says that the police have strengthened the security at the synagogue in Oslo]. Aftenposten. https://www.aftenposten. no/osloby/i/kayJk/Sier-at-politiet-har-styrket-vaktholdet-ved-synagogen-i-Oslo

United Nations. (2019). United Nations strategy and plan of action on hate speech. https://www.un.org/en/ genocideprevention/hate-speech-strategy.shtml

Welch, D. (2002). The Third Reich: Politics and propaganda (2nd ed.). London: Routledge. https://doi. org/10.4324/9780203930144

(C) 2021 Nordicom and respective authors. This is an Open Access work licensed under the terms of the Creative Commons Attribution-NonCommercial-NoDerivatives 4.0 International Public licence (CC BY-NC-ND 4.0). To view a copy of the licence, visit https://creativecommons.org/ licenses/by-nc-nd/4.0/ 